tissues is increased for the benefit of the zooxanthellæ. The phagocytes, carrying the zooxanthellæ from the mantle, surround the reduced diverticula and other regions of the gut and contain these algæ in all stages of digestion. Tridacna, and to a less extent Hippopus, consumes a number of these, so obtaining a significant amount of food.

The mouth is small, there is no sorting mechanism in the stomach, and the selective action of the gills and palps is highly developed, particles $14 \mu$ in diameter being rejected. Assimilation and intercellular digestion take place in the much-reduced digestive diverticula and also in the phagocytic blood cells which may pass through the lumen of the gut. Indigestible material remaining in the phagocytes is presumably carried to the kidneys, which explains the abnormal size of these and the presence within them of a great number of large concre. tions.

The Tridacnidæ are profoundly modified for the housing and final digestion of the zooxanthellæ, and Tridacna may be considered the supreme example of the exploitation of associated algæ by an animal, although unlike Convoluta, roscoffensis it never loses the power of holozoic nutrition, and so only the surplus zooxanthellæ are consumed. Experiments failed to reveal any significant production of oxygen or removal of carbon dioxide by the zooxanthellæ in the light, but they automatically remove all phosphorus excreted by the animal and even the phosphorus present in the water around. This may be the limiting factor controlling their abundance.

In no case known where there is a partnership of algæ with an animal has it been so highly evolved as in Tridacna, resulting in the actual farming of the zooxanthellæ by the mollusc. Every stage in the evolution shows a step towards this end. In a Cardium-like ancestor, it is suggested that the zooxanthellæ first settled in the region of the siphons, having been taken in with the food and so ingested by wandering phagocytes. This partnership being of advantage to both alga and molluse, but especially to the latter, the molluse became so modified in structure that the largest possible surface might be exposed in which the algæe could dwell near the light, whilst with a larger consumption of these the ordinary digestive organs were more and more reduced, a very good combined method of feeding being the result, the boring forms having evolved after this adaptation of structure and functions. It is found that boring is entirely mechanical and that the byssus takes an essential part in this process.

\title{
Bacterial Epidemiology and Nutrition
}

A TEAM of statisticians and bacteriologists who for many years have been investigating experimentally the spread of epidemics of bacterial diseases caused by Bacterium aertrycke and Pasteurello muriseptica in herds of mice under controlled conditions, have now summarized the results of their published work with the addition of some new observations, including an account of epidemics of ectromelia, a virus disease of mice ${ }^{1}$.

To the epidemiologist the work is of great interest and value, and many important conclusions emerge from it. It is found that the average resistance of surviving mice increases with survival in a herd, but never becomes absolute, and in the long run the great majority eventually succumb to the reigning disease, nor will the disease ever normally die out provided the herd does not become too small. The increased average resistance displayed by surviving mice is attributed to natural immunization.

It is considered proved that artificial immunization does confer a high degree of resistance, being more effective in a virus condition like ectromelia than in a bacterial disease like mouse typhoid. Experiments on the influence of 'bacteriophage' on mouse typhoid yielded entirely negative results. It is considered that a major importance may be attached in the genesis of epidemics to the evolution or importation of 'epidemic strains' of particular bacteria or viruses, and that association of two infecting agents may play a part in determining the character of an epidemic.

It seems to be clear that the amelioration or disappearance of an endemic or epidemic infection is more often the result of a summation of effects, many of them unidentifiable, than of any single known factor.
Mr. Knight has recently brought together in convenient form the available information respecting bacterial nutrition ${ }^{2}$. Knowledge of the conditions favouring or inhibiting bacterial development is of importance in bacteriological technique and in the study and control of infective diseases and morbid states, as well as indicating relationships which suggest the possible evolutionary scheme of the bacteria, particularly as it relates to parasitism.

The report is divided into three parts, of which the first and longest gives a systematic survey of the known facts, and summarizes the chemistry of bacterial metabolism and the nutritional requirements of bacteria. In the second part, these nutritional observations are co-ordinated, a brief attempt is made to develop an evolutionary scheme, and the parallelism between nutrient requirements and the development of pathogenic properties and parasitism is illustrated. In the final part, methods are described by which bacteria may be 'trained' and 'adapted' to a simpler mode of life, and the mechanism of nutritional variation is discussed.

There is much in Mr. Knight's report of interest to the general bacteriologist, such as his critical review of the gaseous requirements of bacteria, the various methods that may be employed for the study of bacterial metabolism, and the differentiation of essential from accessory food substances in relation to bacterial growth.

1 Medical Research Council. Special Report Series, No. 209: Experimental Epidemiology. By Dr. M. Greenwood, Dr. A. Bradford Hill, Dr. W. W. C. Topley and J. Wilson. Pp. 204. (London : H.M. Stationery Office, 1936.) 3s. $6 d$, net.

- Medical Research Council. Special Report Series, No. 210 : Bacterial Nutrition; Material for a Comparative Physiology of Bacterial Nutrition; Material for a Comparative Physiology of
Bacteria. By B. C. J. G. Knight. Pp. 182. (London: H.M. Stationery Bacteria. By B. C. J. C. 